\title{
HEMOPHAGOCYTOSIS SECONDARY TO PHARYNGEAL ABSCESS IN AN IMMUNOCOMPETENT PATIENT (case report)
}

\author{
I. D. Khan, M. Malik, K. S. Rajmohan, P. Banerjee, S. Khan, P. S. Panda, \\ M. Brijwal, S. Gupta, Kahkasha, S. Gazala, E. Sawarat, M. S. Aguinaga \\ ARMY COLLEGE OF MEDICAL SCIENCES AND BASE HOSPITAL, NEW DELHI, INDIA
}

Background. Hemophagocytosis is a rare, potentially fatal disorder, comprising pancytopenia, liver dysfunction, hepatosplenomegaly, hypertriglyceridemia, and hyperferritinemia presenting as fever, lymphadenopathy and skin rashes.

Objective. To attract the clinicians'attention to a problem of hemophagocytosis in Critical Care management.

Methods. Hemophagocytosis secondary to pharyngeal abscess in a 58 year old male is being reported.

Results. A 58-year-old immunocompetent patient presenting with hemophagocytosis secondary to pharyngeal abscess, was managed on ventilator and inotropic support, when he developed heathcare-associated urinary tract infection by Escherichia coli and ventilator-associated pneumonia by Acinetobacter baumanii. He developed neutropenic septic shock and multi-organ dysfunction and went through a downhill course leading to demise.

Conclusions. Hemophagocytosis remains a sinister entity in modern intensive care despite astute clinical management. Secondary superinfections with opportunistic multidrug resistant pathogens are difficult to treat. A high index of clinical suspicion, aggressive diagnosis and prompt treatment for hemophagocytosis and polymicrobial opportunistic superinfections with multidrug-resistant healthcare-associated pathogens needs to be addressed upfront.

KEY WORDS: hemophagocytosis; pharyngeal abscess; Acinetobacter baumanii; pancytopenia; ventilator-associated pneumonia; sepsis.

\section{Introduction}

Hemophagocytosis is a rare, potentially fatal disorder, comprising pancytopenia, liver dysfunction, hepatosplenomegaly, hypertriglyceridemia, and hyperferritinemia presenting as fever, lymphadenopathy and skin rashes. Primary hemophagocytosis may be genetic (X-linked lymphoproliferative syndrome and Chediak-Higashi syndrome), while secondary hemophagocytosis may occur due to infections, malignancies (lymphomas) and autoimmune diseases (sarcoidosis). Bacterial infections causing hemophagocytosis are tuberculosis, typhoid, brucellosis and ehrlichiosis. Many viruses such as swine influenza H1N1, avian influenza, measles, Epstein-Barr virus, human immunodeficiency virus, parvovirus, hepatitis viruses, herpes viruses and Varicella zoster virus, parasitic diseases such as leishmaniasis, systemic mycosis and various emerging pathogens can also cause hemophagocytosis $[1,2,3,4,5]$.

Corresponding author: Dr Inam Danish Khan, Associate Professor, Clinical Microbiology and Infectious Diseases, Army College of Medical Sciences and Base Hospital, New Delhi 110010, India

E-mail: titan_afmc@yahoo.com

Mobile phone: +918076324060
Antigenic stimuli cause a progressive immune reaction with a cytokine storm, activate macrophages phagocytose erythrocytes and leucocytes in bone marrow and lymphoid tissues. Hemophagocytosis secondary to pharyngeal abscess in a 58 year old male is being reported.

\section{Case Report}

A 58 year old male with mild odynophagia and nasal congestion of three year duration along with high grade continuous fever of one month duration, was referred to a tertiary-care facility. On examination at arrival, the patient had an intoxicated appearance with tachycardia, tachypnea, fever $105.3^{\circ} \mathrm{F}$, pallor and weight $66 \mathrm{~kg}$. He was nursed in intensive care after tracheostomy with ventilator support in synchronized intermittent mandatory ventilation (SIMV) mode along with inotropic support for worsening hypotension. Ventilator was readjusted to continuous positive airway pressure (CPAP) mode. Central venous pressure was $8 \mathrm{~mm} \mathrm{Hg}$. Hot potato voice and nasal twang were evidenced along with oral mucositis and coated tongue. Oedematous and erythematous soft palate with superficial slough was present. 
Ulcer on posterior pharyngeal wall extending from soft palate to floor of vallecula and multiple aphthous ulcers along the lateral border of tongue were evidenced. Bilateral congested palpebral conjunctiva and arcus senilis were also present. Ultrasonography revealed subcutaneous emphysema chest, hepatomegaly, distended gall bladder and grade II prostatomegaly. CECT chest revealed bilateral ground glass opacities in lung bases and early interstitial lung disease in posterobasal segment of right lung. Repeat NCCT neck revealed mass in right pyriform fossa which was confirmed by spiral CT neck, obliteration of right pyriform sinus, thickening of right aryepiglottic folds with restriction of right true vocal cord movement suggestive of mass lesion. MRI showed diffuse oedema and thickening of posterior naso-oro-hypopharyngeal walls with effacement of right pyriform sinus and significant compromise of lumen. Acute pansinusitis, bilateral mastoiditis, bilateral pleural effusion and fibrotic opacity right lung were evidenced. Subcutaneous emphysema of right subclavian region was present. History of low-grade continuous fever two months prior to highgrade fever was elicited for which he was treated with injectable antimicrobials with little improvement. There was history of loose stools 10-12 times and weight loss $2.5 \mathrm{~kg}$ over past three months. He underwent septoplasty three years earlier.

During the course of his illness, haemoglobin dropped from $10 \mathrm{gm} / \mathrm{dl}$ to $7.5 \mathrm{gm} / \mathrm{dl}$ with leukopenia reducing from $3600 / \mathrm{cu} \mathrm{mm}$ to $900 /$ cu mm with neutrophil count $600 / \mathrm{cu} \mathrm{mm}$. Erythrocyte sedimentation rate increased from 45 to 96 in one hour. Anaemia workup revealed mean corpuscular volume $69 \mathrm{fl}$, serum iron $23 \mu \mathrm{g} / \mathrm{dl}$, total iron binding capacity $936 \mu \mathrm{g} / \mathrm{dl}$, ferritin $280 \mu \mathrm{g} / \mathrm{dl}$. Liver function tests included total bilirubin $3.4 \mathrm{mg} / \mathrm{dl}$, direct bilirubin $0.6 \mathrm{mg} / \mathrm{dl}$, alanine and aspartate aminotransferases 125 and $55 \mathrm{mg} / \mathrm{dl}$, alkaline phosphatase $78 \mathrm{mg} / \mathrm{dl}$ and gamma glutamyl transferase $180 \mathrm{mg} / \mathrm{dl}$. Coagulation profile was deranged with INR 2.6, d-dimers $3.17 \mu \mathrm{g} / \mathrm{l}$ and features of early disseminated intravascular coagulation. Dyselectrolytemia and hypocalcaemia persisted. Serum IgA and IgM were raised. Serum protein electrophoresis revealed polyclonal bands in gamma regions. Microbiological work up including Mantoux test, tuberculosis polymerase chain reaction, widal test, malarial serology, tests for HIV, syphilis, Hepatitis B and Clostridium difficile toxin were negative. Blood cultures were negative, urine cultures revealed Escherichia coli. Throat swab revealed Streptococcus viridans and budding yeast cells. Tracheal aspirates revealed Acinetobacter baumanii susceptible to colistin and Cryptococcus laurentii which was susceptible to all antifungals. Histopathological work up involving punch biopsy from pharyngeal wall and nasopharynx revealed chronic inflammatory posterior pharyngeal wall abscess. Repeat biopsy revealed acute ulceration with granulomatous tissue without malignant cells. Bone marrow biopsy revealed reactive marrow with brisk haemophagocytosis. Vasculitis work up was negative. No blasts or atypical cells were seen. Rheumatologic workup for both anti-neutrophil cytoplasmic antibodies and myeloperoxidase were not contributory, however C-reactive proteins and gamma glutamyl transferase were raised. Whole body dual-time Positron Emission Tomography (PET)fludeoxyglucose F 18 (FDG) scan revealed avid inflammatory lesions in oropharynx and nonFDG avid mass in left pharyngeal spaces along with bony erosions in cervical vertebral bodies with adjacent soft tissue attenuation. A host of other investigations such as thyroid profile, vitamin B-12 assay, upper gastrointestinal endoscopy were not contributory. Neutropenic septic shock and multi-organ dysfunction developed and the patient went through a downhill course leading to demise.

\section{Discussion}

Deep seated abscesses in pharyngeal spaces can be present insidiously with prolonged fever which may be difficult to localize and treat. Apart from features of infection such as fever, they can cause pressure effects leading to variable degrees of dysphagia, odynophagia and respiratory obstruction and/or compromise. The abscess can spread to contiguous areas or the inflammation can affect surrounding tissues. Pre-existing comorbidities can lead to rapid worsening of general condition despite the infection being localized, which may also preclude surgical intervention $[6,7]$. Conditions leading to hemophagocytosis can also cause granulomatous hepatitis. Hemophagocytosis in this patient appears to be due to multiple etiology causing immunological stimulation in parallel. Hemophagocytosis is known to occur in patients under intensive-care leading to sepsis and multiple organ failure as evidenced in this patient [8]. Unexplained hypotension requiring inotropic support in this patient is likely to be due to pre-existing disease conditions 
such as pulmonary emphysema and liver disorder. Pancytopenia in hemophagocytosis can lead to immunocompromised state facilitating opportunistic infections such as healthcareassociated urinary tract infection and ventilatorassociated pneumonia. Acinetobacter baumanii was multidrug resistant and was susceptible only to colistin. Secondary superinfections with opportunistic multidrug resistant pathogens were difficult to treat $[9,10,11,12]$. CT, MRI and histopathology localized the same lesion without detection of any other foci [13]. Whole body dual-time PET-FDG scan revealed avid inflammatory lesions in oropharynx which could suggest active disease and non-FDG avid mass in left pharyngeal spaces hints towards a latent tuberculosis infection. Also the bony erosions in cervical vertebral bodies with adjacent soft tissue attenuation point towards involvement of cervical spine.

Retropharyngeal space abscesses are a disease of infancy, usually resulting from abscess of lymph nodes draining infection of ear, nose or throat $[14,15]$. Chronic inflammatory posterior pharyngeal wall abscess is usually evidenced in adults or slightly elder children. Retropharyngeal abscess in adults is often pyogenic and usually secondary to pharyngeal or oesophageal perforation, sepsis in the throat or sinuses, penetrating injury, oral endotracheal intubation or trauma to pharynx. Retropharyngeal tuberculous abscess can rarely be present with odynophagia, neck pain, stridor, mediastinitis and life-threatening respiratory obstruction. Diagnostic limitations preclude diagnostic outcome despite clinical intuition, especially in emerging and rare pathogens [16, $17,18,19,20,21]$.

\section{Conclusions}

Hemophagocytosis remains a sinister entity in contemporary intensive care despite astute clinical management. A high index of clinical suspicion, aggressive diagnosis and prompt treatment for hemophagocytosis and polymicrobial opportunistic superinfections with multidrug-resistant healthcare-associated pathogens needs to be addressed upfront.

\title{
ГЕМОФАГОЦИТОЗ ВНАСЛІДОК ГЛОТКОВОГО АБСЦЕСУ В ІМУНОКОМПЕТЕНТНОГО ПАЦІЕНТА (КЛІНІЧНИЙ ВИПАДОК)
}

\author{
I. D. Khan, M. Malik, K. S. Rajmohan, P. Banerjee, S. Khan, P. S. Panda, M. Brijwal, S. Gupta, \\ Kahkasha, S. Gazala, E. Sawarat, M. S. Aguinaga \\ ARMY COLLEGE OF MEDICAL SCIENCES AND BASE HOSPITAL, NEW DELHI, INDIA
}

Вступ. Гемофагоцитоз - че рідкісний, потенційно небезпечний для життя розлад, який включає панцитопенію, порушення функції печінки, гепатоспленомегалію, гіпертригліцеридемію і гіперферритинемію, та проявляється у вигляді лихоманки, лімфадентопатії та шкірних висипань.

Мета дослідження привернути увагу лікарів до проблеми гемофагоцитозу у відділеннях невідкладної допомоги.

Методи. Описано клінічний випадок гемофагоцитозу, який розвинувся на фоні глоткового абсцесу в чоловіка 58 років.

Результати. 58-річний імунокомпетентний пацієнт з гемофагоцитозом на фоні глоткового абсцесу перебував на штучній вентиляції легень та отримував інотропну фармакотерапію (кардіотоніки), коли у нього розвинулась інфекція сечовивідних шляхів, спричинена Escherichia coli ma вентиляційна пневмонія, спричинену Acinetobacter bаumanii. У пацієнта розвинувся нейтропенічний септичний шок і мультиорганна недостатність, які призвели до його смерті.

Висновки. Незважаючи на інтенсивну терапію та сучасні засоби і методи лікування, гемофагоцитоз залишається небезпечним для життя станом. Вторинні суперінфекції, спричинені опортуністичними мультирезистентними патогенами, важко піддаються лікуванню. Клінічна настороженість, агресивна діагностика, раннє лікування гемофагоцитозу та мультирезистентних опортуністичних суперінфекцій є необхідністю у відділеннях інтенсивної терапії.

КЛЮЧОВІ СЛОВА: гемофагоцитоз; глотковий абсцес; Acinetobacter baumanii; панцитопенія; вентиляційна пневмонія; сепсис. 


\section{References}

1. Takahashi N, Chubachi A, Kume M, et al. A clinical analysis of 52 adult patients with hemophagocytic syndrome: the prognostic significance of the underlying diseases. Int J Hematol. 2001;74:209-13.

2. Brastianos PK, Swanson JW, Torbenson M, Sperati J, Karakousis PC. Tuberculosis-associated haemophagocytic syndrome. Lancet Infect Dis. 2006 Jul;6(7):447-54.

3. Kumar N, Gadpayle AK, Singh R, Tonk RS Dembla G. Epstein-Barr virus-induced haemophagocytic syndrome. Natl Med J India. 2012 SepOct;25(5):271-3.

4. Khan ID, Sahni AK, Bharadwaj R, Lall M, Jindal AK, Sashindran VK. Emerging organisms in a tertiary healthcare set up. Med J Armed Forces India 2014; 70(2):120-128.

5. Johnson TM, Brown MS, Rabbat M, Slim J. Hemophagocytic Lymphohistiocytosis associated with anaplasmosis. Journal of Global Infectious Diseases. 2017;9(2):76-78.

6. Gaglani MJ, Edwards MS. Clinical indicators of childhood retropharyngeal abscess. Am J Emerg Med. 1995 May;13(3):333-336.

7. Hashmi HRT, Mishra R, Niazi M, Venkatram S, Diaz-Fuentes G. An unusual triad of hemophagocytic syndrome, lymphoma and tuberculosis in a non-HIV patient. The American Journal of Case Reports. 2017; 18:739-745.

8. Rekik R, Morazin F, Lumbroso A, Stirnemann J, Montravers P, Gauzit R. Reactive haemophagocytic syndrome and multiple organ failure in intensive care unit patients. Ann Fr Anesth Reanim. 2004 Dec;23(12):1189-1191.

9. Khan ID, Sahni AK. Bacterial infections and emerging resistance in renal transplant recipients. Bang J Med Sci. 2015;14(1):14-21.

10. Khan ID, Basu A, Kiran S, Trivedi S, Pandit $P$, Chattoraj A. Device-associated healthcare associated infections (DA-HAI) and the caveat of multiresistance in a multidisciplinary Intensive Care Unit. Med J Armed Forces India 2017;73(3):222-231.

11. Khan ID, Gupta RM, Sen S, Rajmohan KS, Jindal AK, Makkar A, et al. Emerging antimicrobial resistance and evolving healthcare: dangerous crossroads for the community and the military. Journal of Archives in Military Medicine. In Press: e12097.
12. Khan ID, Dogra PM, Ramphal SK, Khan S, Konar J, Palit A, Srivastava N, Agrawal P, Haleem S, Alam S. Polymicrobial infections in a teenaged renal transplantrecipient. J Basic \& Clin Med 2015,4(1): 37-39.

13. Silva-Herzog E, Detweiler CS. Intracellular microbes and haemophagocytosis. Cellular microbiology. 2008;10(11):2151-2158.

14. Mohamad I, Jaafar R. An elderly man with acute anterior neck pain and odynophagia after a meal. Malaysian Family Physician: the Official Journal of the Academy of Family Physicians of Malaysia. 2013;8(3):37-39.

15. Poorey VK, Karkare A. Retropharyngeal abscess following accidental throttling. Indian Journal of Otolaryngology and Head \& Neck Surgery. 1998;50(3):275-276.

16. Khan ID, Gupta N, Rangan NM, Singh $\mathrm{R}_{\text {, }}$ Sharma AK, Khurana A, Rudra P, Krushnarao MS. Evaluation of pre and post analytical variables in clinical microbiology services in multidisciplinary ICU of a Medical College and Tertiary Care Hospital. J Basic \& Clin Med 2016,5(1):2-4.

17. Khan ID, Lall M, Sen S, Ninawe SM, Chandola P. Multiresistant Elizabethkingia meningoseptica infections in tertiary care. MJAFI 2014;71(3):66-67.

18. Khan ID, Mukherjee T, Gupta S, Haleem S, Sahni AK, Banerjee S, Konar J. Ochrobactrum anthropi sepsis in intensive tertiary care. J Basic \& Clin Med 2014,3(1):18-20.

19. Khan ID, Sahni AK, Bharadwaj R, Anwar I, Jain V, Khan S, Chowdhury A, Dwivedi AK, Gupta AK, Shamsuzzaman, Alam S, Konar J. Cerebral toxoplasmosis diagnosed by stereotactic brain biopsy leading to detection of HIV infection. J Basic \& Clin Med 2016,5(1):5-7.

20. Khan ID. Outbreak of Prototheca wickerhamii algaemia and sepsis in a tertiary care chemotherapy oncology unit. International Journal of Infectious Diseases. 2016 Apr 30;45:195.

21. Khan ID, Rajmohan KS, Gupta RM, Sen $S_{\text {, }}$ Hashmi A, Ninawe SM, Mukherjee B, Kishore K, Mishra M, Yadav A, Choubey A, Shaikh S. Invasive cerebral and pulmonary mucormycosis in an immunocompromised patient. J Basic \& Clin Med 2017,6(2):9-11. 